\title{
Phase response properties of an idealized half-center oscillator
}

\author{
Tamara J Schlichter $^{1 *}$, Brian Mulloney ${ }^{2}$, Carmen Smarandache ${ }^{2}$, Timothy J Lewis ${ }^{1}$ \\ From Nineteenth Annual Computational Neuroscience Meeting: CNS*2010 \\ San Antonio, TX, USA. 24-30 July 2010
}

Half-center oscillators are widely used as models for central pattern generators. They consist of two cells (or groups of cells) connected by relatively strong reciprocal inhibition. Typically, the individual cells are phaselocked in an anti-phase state, where one cell is active while the other is suppressed, and vice versa. In central pattern generators, this allows for the alternating order of two usually opposing behaviors. Often, central pattern generators are coupled, forming networks that coordinate rhythmic activity, such as in the coordinated limb movement during locomotion. Understanding the mechanisms underlying this coordination is an important issue in neuroscience.

The neural circuitry of the crayfish swimmeret system is ideal for exploring coordination, and phase-locking in general, in coupled central pattern generators. It is composed of four bilateral segments each containing two modules equipped with a half-center oscillator that controls a corresponding limb. The half-center oscillator of each module is capable of oscillations independent of other modules, however all modules are connected to each other through well-described inter-segmental coupling. The coupling between cells in the half-center oscillators is relatively strong, whereas the inter-segmental coupling between the half-center oscillators is relatively weak. Therefore, it should be possible to use the theory of weakly coupled oscillators to deduce how phase-locking is achieved in the swimmeret system. However, before this theory can be applied, we need to know the phase response properties of the half-center oscillators that comprise the individual modules. Furthermore, to fully understand the mechanisms underlying phase-locking in these systems, we need to understand how the intrinsic dynamics of the cells and the coupling properties interact to produce the phase response properties of the half-center oscillator.

To gain insight into these issues, we examine the phase response properties of idealized models of half-center oscillators. The dynamics of the cells in the half-center oscillator are described by either the leaky integrateand-fire model or a general one-variable phase model; the coupling between the cells is described by either delta-function pulse coupling or current-based exponential synapses. We obtain analytical or semi-analytical solutions for the phase response curves (PRCs) of these idealized half-center oscillators, which show how the cells' individual PRC and the coupling dynamics produce the PRC of the half-center oscillator. We compare our analytical results to numerical simulations of more realistic models and experimental data from the crayfish swimmeret system. We also discuss the implications for phaselocking in networks of half-center oscillators.

\section{Acknowledgements}

This work was supported by NSF grant IOS-0905063.

\section{Author details}

${ }^{1}$ Department of Mathematics, University of California, Davis, Ca 95616, USA. ${ }^{2}$ Department of Neurobiology, Physiology and Behavior, University of California, Davis, Ca, 95616, UK

Published: 20 July 2010

\section{doi:10.1186/1471-2202-11-S1-P3}

Cite this article as: Schlichter et al:: Phase response properties of an idealized half-center oscillator. BMC Neuroscience 2010 11(Suppl 1):P3.

* Correspondence: tamijoy@math.ucdavis.edu

${ }^{1}$ Department of Mathematics, University of California, Davis, Ca 95616, USA 